\title{
The Impact of Marine Aquaculture on the Environment; the Importance of Site Selection and Carrying Capacity
}

\author{
Guzel Yucel-Gier*, Canan Eronat, Erdem Sayin \\ Institute of Marine Sciences and Technology, Dokuz Eylül University, Haydar Aliyev Bld, No: 100, Inciralt1, Izmir, Turkey \\ Email: *yucel.gier@deu.edu.tr
}

How to cite this paper: Yucel-Gier, G., Eronat, C. and Sayin, E. (2019) The Impact of Marine Aquaculture on the Environment; the Importance of Site Selection and Carrying Capacity. Agricultural Sciences, 10, 259-266.

https://doi.org/10.4236/as.2019.103022

Received: January 30, 2019

Accepted: March 8, 2019

Published: March 11, 2019

\begin{abstract}
A growing increase in the world's population and a gradual decline in poverty necessitate a search for new sources of protein in order to guarantee food security. Aquaculture has been identified as a potential sector capable of meeting the requirements for increased protein production without making excessive demands on the ecosystem. Although water makes up 70\% of the earth's surface, aquaculture cannot feasibly be practised everywhere; it requires a unique set of natural, social and economic resources to be managed in an environmentally responsible way. Finding suitable sites for aquaculture is becoming an ever increasing problem in the development of the sector as precautions need to be taken in setting up sites to ensure appropriate environmental characteristics exist and that good water quality can be maintained. Additionally, the effects of aquaculture on coastal and inland resources must be clearly determined to implement policies and regulatory frameworks to control its impact. Marine cage farming is gaining momentum, specifically in the Mediterranean and Black Sea coastal regions. For these sites to be further developed there is a need to minimize the effects on the environment and conflicts with other coastal users. To this aim the concept of allocated zones for aquaculture (AZA) is being adopted to provide specific areas for marine aquaculture to avoid environmental degradation. When choosing an (AZA) suitable site, it is vital to calculate 'carrying capacity' to reduce the risks and to protect the marine ecosystems. In this study the MERAMOD model was used to investigate the carrying capacity of marine fish farms. Modelling offers the possibility to simulate and predict the environmental impact of fish farms.
\end{abstract}

\section{Keywords}

Environment, Marine Aquaculture, Site, Carrying Capacity 


\section{Introduction}

The total production of farmed food fish was80million tonnes, aquatic plants 30.1 million tonnes and non-food products 37,900 tonnes. Farmed food fish production consists of; finfish 54.1 million tonnes, molluscs 17.1 million tonnes, crustaceans 7.9 million tonnes and other aquatic animals like turtles, sea cucumbers, sea urchins, frogs and edible jellyfish 938,500 tonnes. The above mentioned aquatic plants are generally seaweeds and although not significant in volume microalgae are also produced. The non-food products included refer only to ornamental shells and pearls [1]. Due to high demand and technological advancements the total world fish production is expected to increase (capture plus aquaculture, excluding aquatic plants) is predict to reach 201 million tonnes by 2030 (Figure 1).

Aquaculture is a functioning and developing industry in the Mediterranean and Black Sea regions, it has a considerable part to play in obtaining food security, employment and economic development for the country, in addition to the afore mentioned benefits, aquaculture reduces overexploitation of wild stocks. By the year 2014 the Mediterranean countries and countries bordering the Black Sea produced almost 2,381,954 tonnes (marine, brackish and freshwater aquaculture), this is expect to increase to 4,600,000 tonnes between 2020-2030 in the long term this accelerated growth will bring challenges to sustainability in the sector and will lead to worries [2]. One of the major worries is finding solutions for the environmental and ecological impacts brought about by increased aqua culture production. To understand the current challenges there is a need for regionally assigned areas called Allowable Zone for Aquaculture (AZA) and the effected zone inside AZA known as Allowable Zone of Effect (AZE). It is important to establish a regulatory process that clearly identifies where aqua cultural facilities can be located and how to instigate a strategy for the sustainable development of aquaculture for the regions mentioned [3].

Marine aquaculture is an industry that includes; breeding of various species, production methods and management. Marine aquaculture (fin-fish) generates particulate and soluble organic waste (faecal and uneaten food) and soluble inorganic excretory waste. The severity of the situation depends on load and the

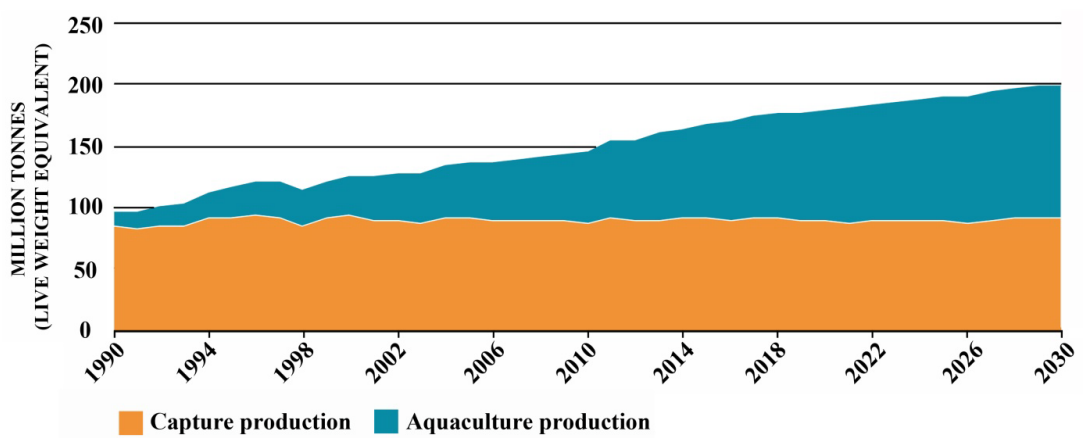

Figure 1. World capture fisheries and aquaculture production, 1990-2030 [1]. 
marine aquaculture in the Mediterranean show that nutrients are rapidly transferring up the trophic chain, indicating that monitoring of nutrient losses should be done at different levels of production [4] [5]. As the feed and faecal pellets settle very quickly near the fish farm, their benthic impacts are extensively reported [6] [7]. Predominantly under the cages, sediment can have considerable effects on the benthic fauna and flora [8] [9] [10]. There are some otherenvironmental impacts, such as the releasing of chemicals, medicines and pesticides, which are used in the treatment of fish in the farm installations. Interactions with wild populations, spreading of disease and release of parasites from farms are also of environmental concern.

Crucially, the possible risks to the marine ecosystem should be calculated, thus determining the site selection and the operation process. In defining AZA the following should be applied; the use of technical procedure, site selection, biological and oceanographic information, ecological and social constraints (i.e. carrying capacities) [3]. The proper environmental management of AZE as well as marine spatial planning should include EIAs, managing monitoring programmes, Aquaculture Management Area (AMA). Carrying Capacity a concept, which is directly, related to the AZE "the maximum production of a species, which can be maintained within an area in relation to the available food and environmental resources" [11].

The objectives of our study were to establish a carrying capacity model is designed to predict the solid deposition from caged sea bass fish farms.

\section{Materials and Methods}

In this study the MERAMOD model was used to investigate the carrying capacity of marine fish farms.

Solid matter accumulation (faeces and feed) around the cages were simulated in different scenarios using production data, feed data, cage layouts, current speed and direction. Solid accumulation quantities were examined in two farms that produced 370 tons/year and 1800 tons per year in each case the discharge intensity changes in $10 \mathrm{~cm} / \mathrm{s}$ and $20 \mathrm{~cm} / \mathrm{s}$ currents. The effect and the impact on the environment by the fish farms are calculated according to the amount of food needed for the sea bass (Dicentrarchuslabrax). FCR is 2 for sea bass.

\section{Result}

Modelling offers the possibility to simulate and predict the environmental impact of sea bass fish farms.

The following scenarios were set; 370 tonnes/year with $10 \mathrm{~cm} / \mathrm{s}$ and $20 \mathrm{~cm} / \mathrm{s}$ current and for 1800 tonnes/year with $10 \mathrm{~cm} / \mathrm{s}$ and $20 \mathrm{~cm} / \mathrm{s}$ current. Regarding the MERAMED Project [12] to determine the extent (area) of the footprint, the sea bed area enclosed by the $500 \mathrm{gr} / \mathrm{m}^{2} / \mathrm{y}$ contour was used as this represents the outer limits of the predicted footprint (MERAMED Project, 2004). 
Scenario 1; Figure 2 illustrates the solid flux is maximum a $3000 \mathrm{gr} / \mathrm{m}^{2} / \mathrm{y}$ and the outer limit of $500 \mathrm{gr} / \mathrm{m}^{2} / \mathrm{yr}$ reminds inside 200 meters' limit $(10 \mathrm{~cm} / \mathrm{s})$ of an area.

Scenario 2; Figure 3 depicts the solid flux is maximum a $2200 \mathrm{gr} / \mathrm{m}^{2} / \mathrm{yr}$ and the outer limit of $500 \mathrm{gr} / \mathrm{m}^{2} / \mathrm{yr}$ reminds inside 300 meters' limit $(20 \mathrm{~cm} / \mathrm{s})$ of an area.

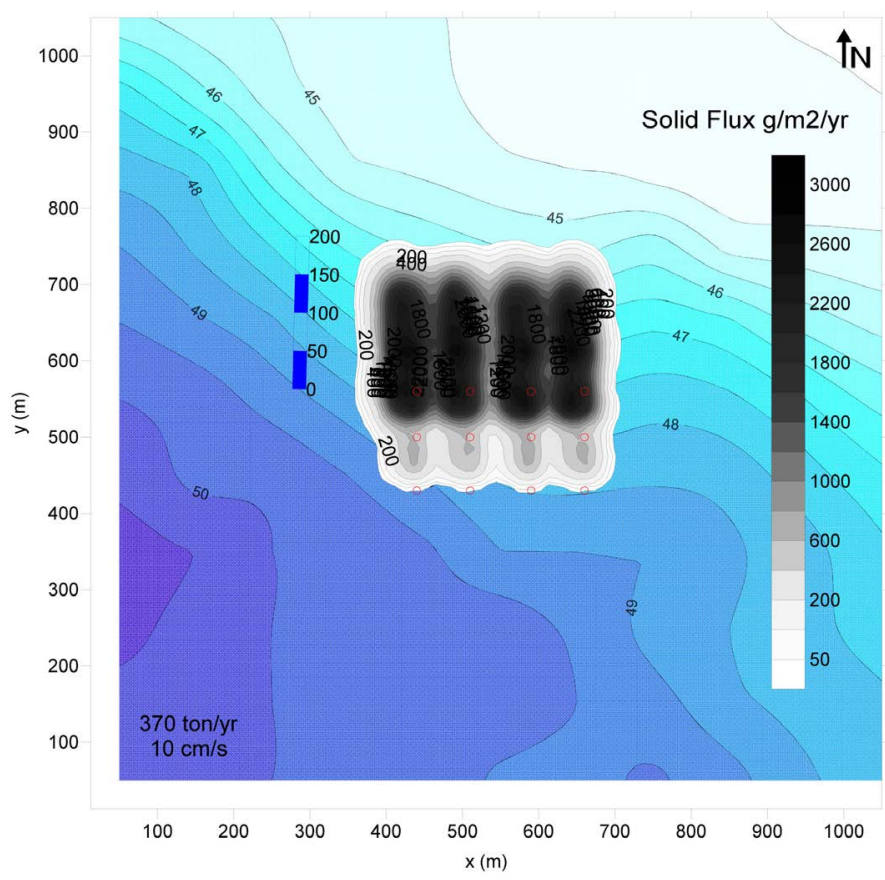

Figure $2.10 \mathrm{~cm} / \mathrm{s}$ current at a 370 ton/year production per year fish farm.

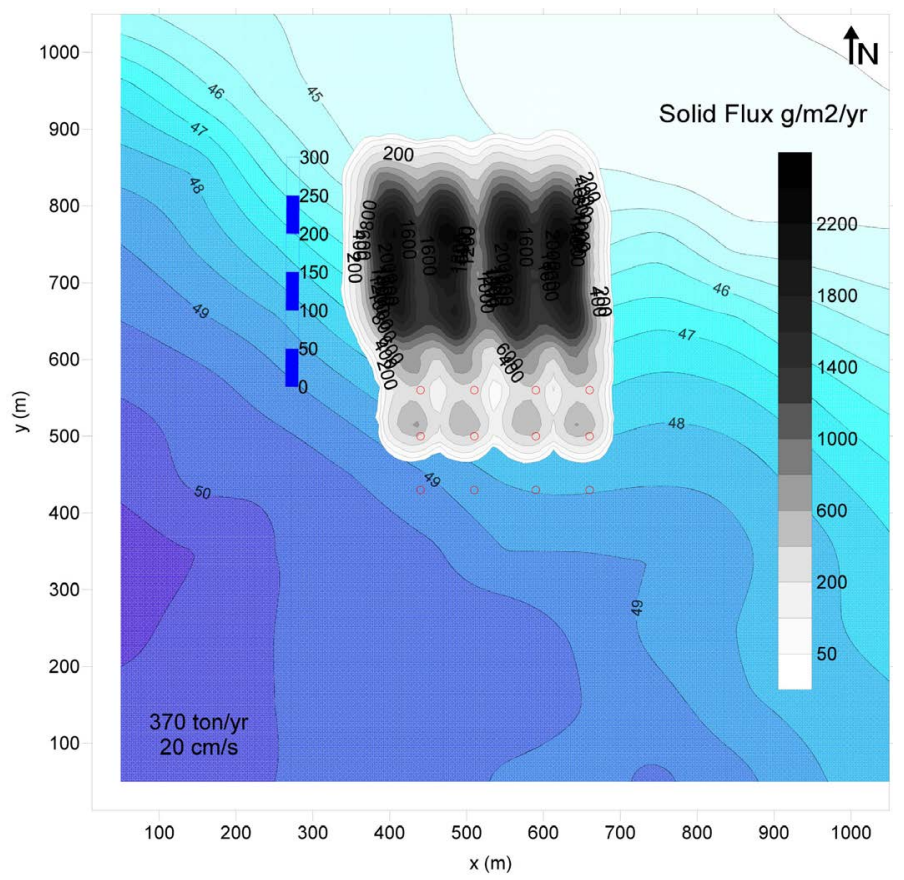

Figure $3.20 \mathrm{~cm} / \mathrm{s}$ current at a 370 ton/year production per year fish farm. 
Scenario 3; Figure 4 depicts the solid flux is maximum a $13,000 \mathrm{gr} / \mathrm{m}^{2} / \mathrm{yr}$ and the outer limit of $500 \mathrm{gr} / \mathrm{m}^{2} / \mathrm{yr}$ reminds inside 200 meters' limit $(10 \mathrm{~cm} / \mathrm{s})$ of an area.

Scenario 4; Figure 5 depicts the solid flux is maximum a1 $1000 \mathrm{gr} / \mathrm{m}^{2} / \mathrm{yr}$ and the outer limit of $500 \mathrm{gr} / \mathrm{m}^{2} / \mathrm{yr}$ reminds inside 300 meters' limit $(10 \mathrm{~cm} / \mathrm{s})$ of an area.

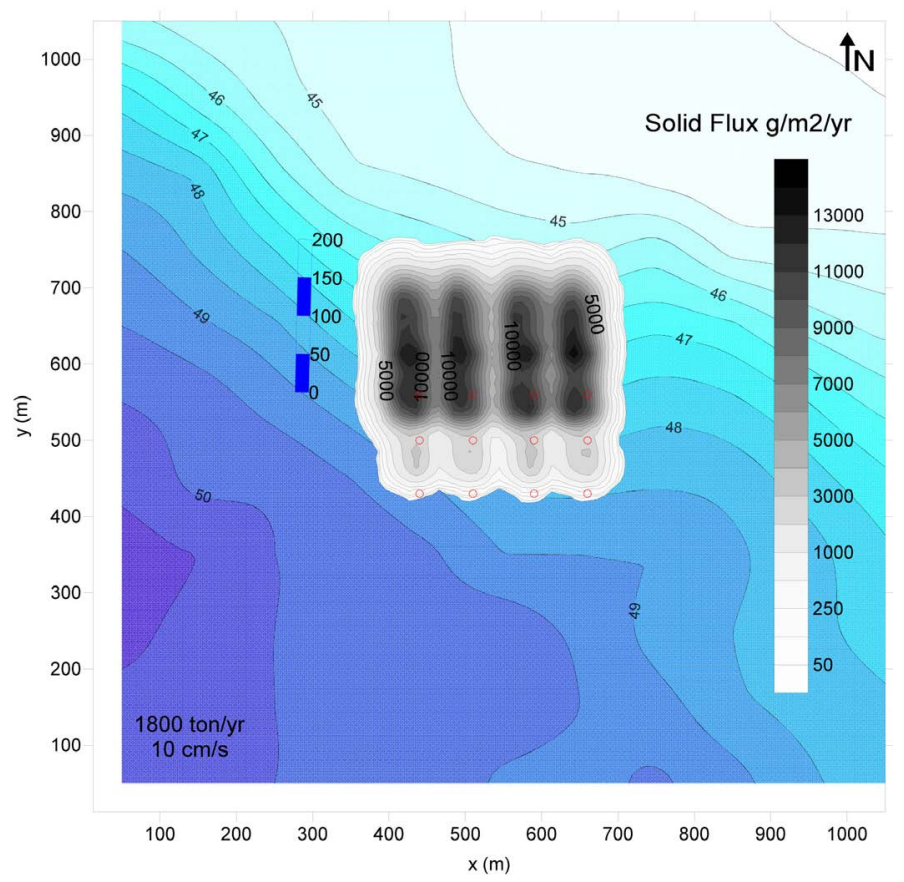

Figure $4.10 \mathrm{~cm} / \mathrm{s}$ current at a 1800 ton/year production per year fish farm.

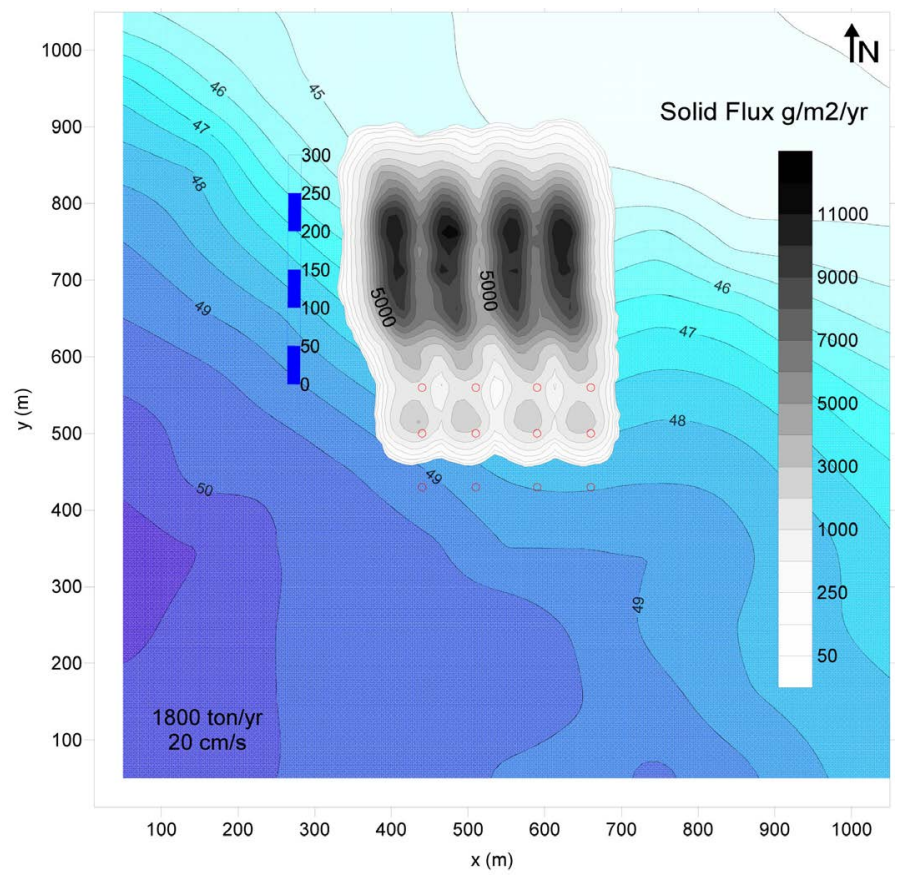

Figure $5.20 \mathrm{~cm} / \mathrm{s}$ current at a 1800 ton/year production per year fish farm. 
When studying the effects and degree of changes in the study areas, horizontal distributions were used to show where the effects decreased as they moved away from the cages. As expected when the production increases the solid flux increase and when the current increases the precipitate spreads over a larger area. This simulation puts forward an e-experience on how sedimentation correlates to production and current.

\section{Discussion and Conclusion}

There are many users of coastal areas so complex interactions occur, one of them is aquaculture because of its need for a specific environment and water quality characteristics. This struggle for marine space has put pressure on marine users especially fisheries, tourism operators, holiday residences. To avoid conflicts, maintain biodiversity and welcome multiple uses a clearly defined use of space should be implemented to manage sustainable development.

Due to its well established past, we know a great deal about salmon production and its benthic impacts, whereas the fish farming industry in the Mediterranean is comparatively new so less is known of its benthic impact.

However in recent years the relationship between particulate waste inputs is now better quantified and understood [13] [14]. When compared faecal particles settle slower than uneaten feed particles and they are seeming under and vicinity of the cages. The sinking of faecal particles in a horizontal flow is much slower between the sea surface and sea bed so they are transported further away from the cages. For instance Wilson et al. 2009 [15] claims regulation and management of seabed impacts is a key component of regulating finfish impacts on salmon farming countries but this is not always the case in Mediterranean aquaculture [16]. For each scenario a contour plot is shown, which is a plan view of the sea bed showing values of predicted solid flux (Figures 2-5).

Darker colours indicate a higher value of flux and thus a higher potential for impact. Within the scope of the Zone Effected Areas (AZE), the region where the effect of aquaculture activities is allowed is defined as the close environment of each farm. Establishing an AZE around a cage or cage set provides a degree of flexibility in the regulation of farms effects. This practice recognises that it is impracticable for there to be no environmental effects from intensive fish production in the immediate vicinity of the cages.

\section{Conclusion}

In this study we observed that when the current was low, the effect of the deposition was localised $(200 \mathrm{~m})$ but as current rose its deposition increased up to 300 meters. The model shows the effects of one-year period. This study took place in two specific fish farms. Further studies should work on multiple farms and cumulative effects in years.

\section{Conflicts of Interest}

The authors declare no conflicts of interest regarding the publication of this paper. 


\section{References}

[1] FAO (2018) The State of World Fisheries and Aquaculture. Meeting the Sustainable Development Goals, Rome, 193 p.

[2] FAO (2017) Report of the Forty-First, Session 41, Montenegro, 16-20 October, Rome, $171 \mathrm{p}$.

[3] Sanchez-Jerez, P., Karakassis, I., Massa, F., Fezzard, D., Aguilar-Manjarrez, J., Soto, D., Chapela, R., Avila, P., Macias, J.C., Tomassetti, P., Marino, G., Borg, J.A., Franičević, V., Yucel-Gier, G., Fleming, X., Biao, H., Nhhala, H., Hamza, A. Forcada, T. and Dempster (2016) Aquaculture's Struggle for Space: The Need I. A. for Coastal Spatial Planning and the Potential Benefits of Allocated Zones for Aquaculture (AZAs) to Avoid Conflict and Promote Sustainability. Aquaculture Environment Interactions, 8, 41-54. https://doi.org/10.3354/aei00161

[4] Machias, A., Karakassis, I., Somarakis, S., Giannoulaki, M., Papadopoulou, K.N. and Smith, C. (2005) The Response of Demersal Fish Communities to the Presence of Fish Farms. Marine Ecology Progress Series, 288, 241-250.

https://doi.org/10.3354/meps288241

[5] Yucel Gier, G., Uslu, O. and Bizsel, N. (2008) Effects of Marine Fish Farming on Nutrient Composition and Plankton Communities in the Eastern Aegean (Turkey).

Aquaculture Research, 39, 181-194. https://doi.org/10.1111/j.1365-2109.2007.01878.x

[6] Holmer, M., Wildish, D. and Hargrave, B. (2005) Organic Enrichment from Marine Finfish Aquaculture and Effects on Sediment Processes. In: Hargrave, B.T., (Ed.), the Handbook of Environmental Chemistry, Vol. 5: Water Pollution Environmental Effects of Marine Finfish Aquaculture, Springer, Berlin Heidelberg New York, 181-206. https://doi.org/10.1007/b136010

[7] Kalantzi, I. and Karakassis, I. (2006) Benthic Impacts of Fish Farming: Meta-Analysis of Community and Geochemical Data. Marine Pollution Bulletin, 52, 484-493. https://doi.org/10.1016/j.marpolbul.2005.09.034

[8] Karakassis, I., Tsapakis, M., Smith, C.J. and Rumohr, H. (2002) Fish Farming Impacts in the Mediterranean Studied through Sediment Profiling Imagery. Marine Ecology Progress Series, 227, 125-133. https://doi.org/10.3354/meps227125

[9] Yucel Gier, G., Kucuksezgin, F. and Foçak, F. (2007) The Effects of Fish Farming on Nutrients and Benthic Community Structure in the Eastern Aegean (Turkey). Aquaculture Research, 38, 256-267. https://doi.org/10.1111/j.1365-2109.2007.01661.x

[10] Kocak, F., Uluturhan, E., Yucel-Gier, G. and Aydın Onen, S. (2011) Impact of Environmental Conditions on Posidoniaoceanica Meadows in the Eastern Mediterranean Sea. Indian Journal of Geo-Marine Sciences, 40, 770-778.

[11] Fernandes, T.F., Eleftheriou, A., Ackefors, H., Eleftheriou, M., Ervik, A., Sanchez-Mata, T., Scanlon, P.W., Cochrane, S., Pearson, T.H. and Read, P.A. (2001) The Scientific Principles Underlying the Monitoring of the Environmental Impacts of Aquaculture. Journal of Applied Ichthyology, 17, 181-193. https://doi.org/10.1046/j.1439-0426.2001.00315.x

[12] MERAMED Project (2004) Development of Monitoring Guidelines and Modelling Tools for Environmental Effects from Mediterranean Aquaculture. A Project Supported by the European Commission through the 5th Framework Programme for "Quality of Life and Management of Living Resources". Newsletter 4.

[13] Papageorgiou, N., Sigala, K. and Karakassis, I. (2009) Changes of Macrofaunal Functional Composition at Sedimentary Habitats in the Vicinity of Fish Farms. Es- 
tuar Coast Shelf Sci, 83, 561-568. https://doi.org/10.1016/j.ecss.2009.05.002

[14] Sanz-Lázaroü, C., Belando, MçD., Marin-Guirao, L., Navarrete-Mier, F. and Marin, A. (2011) Relationship between Sedimentation Rates and Benthic Impact on Maërl Beds Derived from Fish Farming in the Mediterranean. Mar Environ Res, 71, 22-30. https://doi.org/10.1016/j.marenvres.2010.09.005

[15] Wilson, A., Magill, S. and Black, K.D. (2009) Review of Environmental Impact Assessment and Monitoring in Salmon Aquaculture. In: Environmental Impact Assessment and Monitoring in Aquaculture, FAO Fish Aquac Tech Pap No. 527. UN FAO, Rome, 455-535.

[16] Telfer, T.C., Atkin, H. and Corner, R.A. (2009) Review of Environmental Impact Assessment and Monitoring in Aquaculture in Europe and North America. In: Environmental Impact Assessment and Monitoring in Aquaculture, FAO, Fish Aquac Tech Pap No. 527, UN FAO, Rome, 285-394. 